\title{
Early Detection of Growth Hormone Secretagogue Receptor Antagonists Exploiting their Atypical Behavior in Competitive Assays
}

\author{
George Madalin Danila ${ }^{\dagger \dagger, \perp}$, Mihaela Puiu ${ }^{\dagger, \perp}$, Lucian-Gabriel Zamfir ${ }^{\dagger, \S}$ and Camelia Bala ${ }^{*} \dagger, \|$ \\ ${ }^{\dagger}$ Laboratory for Quality Control and Process Monitoring, University of Bucharest, 030018 Bucharest, Romania \\ †Romanian Doping Control Laboratory, 022103 Bucharest, Romania \\ § ICUB, University of Bucharest, 050107 Bucharest, Romania \\ " Department of Analytical Chemistry, University of Bucharest, 030018-Bucharest, Romania.
}

*Camelia Bala, Department of Analytical Chemistry, University of Bucharest, 030018-Bucharest, Romania

E-mail: camelia.bala@chimie.unibuc.ro; 


\section{Supporting Information Available}

Material and Methods Section:

Parameter Optimization Section
Pages S3-S6

Pages S6-S9

Supplementary Tables:

Table S1 Optimization of streptavidin concentration and $\mathrm{pH}$ buffer in the coating process of the microplate. Page S6

Table S2 Affinity/dissociation constants estimated through non-linear regression analysis using the "two-binding site" model for competitive binding assays with bio-GHR and antagonists $\left(10 \mathrm{mM} \mathrm{PBS}\right.$ buffer, $\mathrm{pH}=7.4$ at $\left.37^{\circ} \mathrm{C}\right) . \quad$ Page $\mathrm{S} 11$

Supplementary figures:

Figure S1 Chemical structure of the GHS-R1a antagonists selected for this study Page S3

Figure S2 Influence of $\mathrm{pH}$ buffer and streptavidin concentration in the coating process of the microplate. The absorbance is directly proportional to amount of biotinylated anti-GHS-R1a bound to the surface and consequently to the adsorbed streptavidin. Acidic pHs provided the highest load of streptavidin.

Page S7

Figure S3: A Blocking of free binding sites of streptavidin after immobilization of antibody; B Blocking of biotinylated antibody anti-GHSR $1 \mathrm{a}(0.5 \mu \mathrm{g} / \mathrm{mL})$ after binding on coated streptavidin with different concentrations of free streptavidin.

Page S8

Figure S4 A bio-conjugate streptavidin-horseradish peroxidase (STR-HRP) was used for detection of biotinylated ghrelin. The optimized concentration of bio-conjugate was $100 \mathrm{ng} / \mathrm{mL}$ prepared in $10 \mathrm{mM}$ PBS buffer containing $1 \%$ BSA and $0.05 \%$ Tween 20 .

Page S9

Figure S5 Calibration curve for the detection of active GHS-R1a receptor in an ELISA sandwich assay. All binding experiments were performed in $10 \mathrm{mM}$ PBS buffer, $\mathrm{pH}=7.4$ and $37^{\circ} \mathrm{C}$.

Page S10

Figure S6 Calibration plots exploiting the linear parts of the binding curves in competitive assays with bio-GHR and antagonists.

Page S12

Figure $\mathbf{S} 7$ Calibration plots for DLS detection in diluted urine samples with PBS $(1: 4 \mathrm{v} / \mathrm{v})$. 


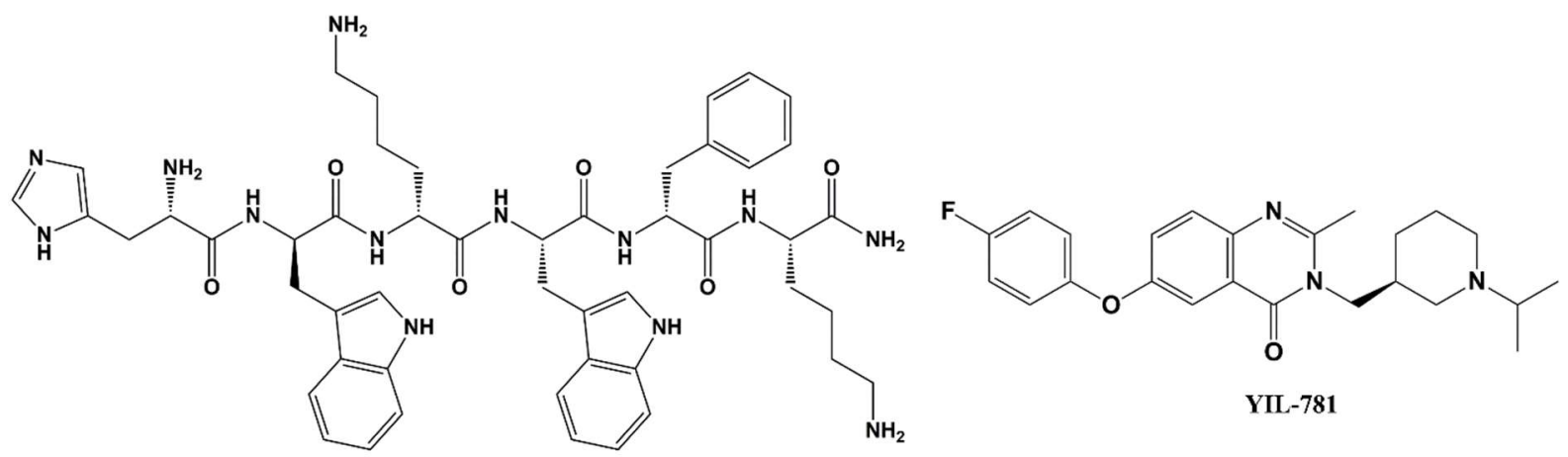

[D-Lys $\left.{ }^{3}\right]-$ GHRP-6

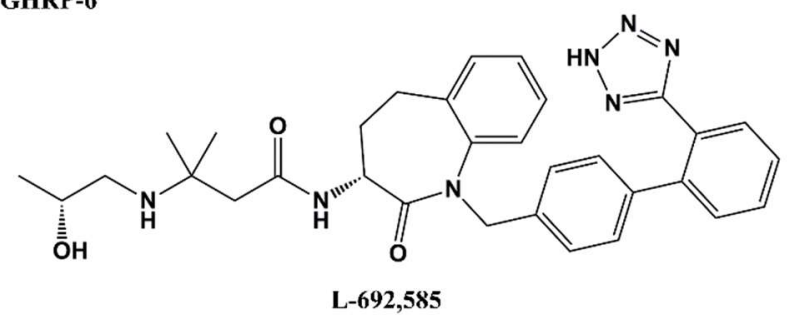

Figure S1 Chemical structure of the GHS-R1a antagonists selected for this study

\section{Materials and methods}

\section{Chemicals}

Reagent-grade chemicals: potassium phosphate monobasic, sodium phosphate dibasic, potassium chloride, sodium chloride, sodium acetate, sodium carbonate, sodium bicarbonateTween 20, and citric acid were purchased from Merck (Kenilworth, NJ, USA). $\mathrm{H}_{2} \mathrm{SO}_{4}$ (purity $>95 \%$ ) was purchased from Fluka (Buchs, Switzerland). $\mathrm{H}_{2} \mathrm{O}_{2}(30 \% \mathrm{w} / \mathrm{w})$, 3,3',5,5'-tetramethylbenzidine (TMB, purity $>99 \%$ ), and $N, N$-dimethylformamide were supplied by Sigma-Aldrich (St. Louis, MO, USA). Synthetic urine (same composition as normal urine - $25 \mathrm{~g} / \mathrm{L}$ urea, $9 \mathrm{~g} / \mathrm{L}$ sodium chloride, $2 \mathrm{~g} / \mathrm{L}$ creatinine, $\mathrm{pH}=6.5$ ) was purchased from DTI (Lenexa, USA).

\section{Biomolecules for multiwell plate assays}


Biotinylated ghrelin, bio-GHR (M.W. $=3600 \mathrm{Da}$, purity $>95 \%$ ) and streptavidin conjugated with horseradish peroxidase (HRP) were purchased from AnaSpec (Freemont, CA, USA). Free biotin, YIL-781 hydrochloride (M.W. = 446 Da, purity > 98\%), [D-Lys ${ }^{3}$ ]-GHRP-6 (M.W. = $930 \mathrm{Da}$, (purity $>98 \%$ ), bovine serum albumin (BSA) were purchased from Sigma-Aldrich (St. Louis, MO, USA). L-692,585 (M.W. = 568Da, purity $>98 \%$ ) was purchased from Tocris Bioscience (UK). Anti-ghrelin receptor (anti-GHS-R1a) antibody (IgG, polyclonal antibody raised in rabbit to ghrelin receptor, $1 \mathrm{mg} / \mathrm{mL}$ IgG solution conjugated with biotin (in PBS at $\mathrm{pH} 7.4$, with $0.09 \%$ sodium azide) was purchased from LSBio (Seattle, WA, USA). Human ghrelin receptor protein (GHS-R1a) was purchased in lyophilized form from Aviva Systems Biology (San Diego, CA, USA). Recombinant human ghrelin receptor protein (M.W. $=58000$ $\mathrm{Da}$, source: wheat germ, $0.05 \mathrm{mg} / \mathrm{mL}$ in $0.79 \%$ TrisHCl) was purchased from Abcam (Cambridge, UK). The 96-wells clear-polystyrene microplates were from Thermo Scientific Nunc (Waltham, MA, USA).

\section{Assay buffers and chromogenic solutions}

$0.01 \mathrm{M}$ phosphate buffer saline (PBS, $\mathrm{pH}=7.4$ ) was employed as diluent for the standard and sample solutions of antibodies and receptor; 0.01M PBS $(\mathrm{pH}=7.4)$ with $0.05 \%$ Tween 20 was used in all washing steps. $0.01 \mathrm{M}$ acetate or acetate/citrate buffers $(\mathrm{pH} \mathrm{3.7,5}$ and 6) were tested to increase the microplate coating efficiency with streptavidin. The streptavidin-HRP bioconjugate solutions were prepared in $0.01 \mathrm{M}$ PBS pH 7.4 with $1 \%$ BSA and $0.05 \%$ Tween 20. The TMB chromogenic substrate was prepared by mixing $20 \mu \mathrm{L}$ of a $10 \mathrm{mg} / \mathrm{mL}$ TMB solution in DMF with $20 \mu \mathrm{L} \mathrm{H}_{2} \mathrm{O}_{2} 0.03 \%$ and $960 \mu \mathrm{L}$ of $0.05 \mathrm{M}$ sodium acetate/citrate buffer $(\mathrm{pH}=6)$. The stop solution for HRP inactivation was $0.18 \mathrm{M} \mathrm{H}_{2} \mathrm{SO}_{4}$. All aqueous solutions were prepared with ultrapure water, obtained with a Direct Q3 system $(18.2 \mathrm{M} \Omega \cdot \mathrm{cm}$, Millipore, Burlington, MA, USA).

\section{Colorimetric assays}

A 96-wells plate reader spectrophotometer with temperature and stirring control was used for the colorimetric protocol development and validation (Thermo Multiskan, Thermo Scientific, Waltham,MA, USA). All measurements were performed at fixed wavelength $(\lambda=450 \mathrm{~nm})$ and at constant temperature $\left(37^{\circ} \mathrm{C}\right)$. Data were processed with Table Curve 2D v.4.0 (Systat Software Inc., San Jose, CA, USA).

\section{Preparation of the support layer for GHS-R1a}


Each microplate well was incubated with $100 \mu \mathrm{L}$ of $2.5 \mu \mathrm{g} / \mathrm{mL}$ streptavidin in $10 \mathrm{mM}$ acetate/citrate buffer ( $\mathrm{pH} \mathrm{5)}$ and kept at $4^{\circ} \mathrm{C}$ overnight. After removing the coating solution, the microplate wells were kept in contact ( 3 x 5 min) with $300 \mu \mathrm{L}$ washing buffer per well. 100 $\mu \mathrm{L}$ of biotinylated anti-GHS-R1a antibody $(1 \mu \mathrm{g} / \mathrm{mL}$ in PBS $\mathrm{pH} 7.4)$ was added to each well and incubated for 2 hours at $37^{\circ} \mathrm{C}$. After removing the antibody solution, the microplate was washed 3 times ( 3 x 5 min) with the washing buffer. Blank experiments were carried out with biotinylated anti-GHS-R1a antibody $(1 \mu \mathrm{g} / \mathrm{mL})$ in the absence of streptavidin to check the contribution of non-specific adsorbed biotinylated antibodies to the background absorbance.

In our approach, the sources of false positive/negative results are the remained binding sites of tetrameric streptavidin coated on wells and the unbounded biotin from the biotinylated antiGHS-R1a antibody. The free binding sites of streptavidin adsorbed onto surface may also capture biontinylated ghrelin which is supposed to bind the GHS-R1a receptor; the free biotin groups from the anti-GHS-Rla antibody may interact with the streptavidin-HRP bioconjugate; To avoid that, we performed first a blocking step with biotin for the surface adsorbed streptavidin; then, after the immobilization of biotinylated anti-GHS-R1a antibody streptavidin was added to bind the free biotin groups from the antibody; finally, free biotin was added again to block the remaining free sites of streptavidin bounded to antibody through the interaction with free biotin.

In the first step, each well was incubated with $2.5 \mu \mathrm{g} / \mathrm{mL}$ free biotin in PBS buffer $(100 \mu \mathrm{L}, 3$ times for 10 minutes at room temperature, RT). In the second step, after the immobilization of the biotinylated anti-GHS-R1a antibody, $100 \mu \mathrm{L}$ of streptavidin $2.5 \mu \mathrm{g} / \mathrm{mL}$ in PBS buffer were added ( 3 times for 10 minutes at RT) in order to block the biotin groups from the antibody which were not bound to the surface. Finally, the surface was blocked by repeating first step and then each well wash washed 3 times with wash buffer.

\section{Competition step}

For the detection purposes, the recombinant human ghrelin receptor was used to capture the ghrelin and its mimetics in a competition step. $50 \mu \mathrm{L}$ of recombinant receptor in PBS buffer (1 $\mu \mathrm{g} / \mathrm{mL}-10 \mathrm{ng} / \mathrm{mL}$ active form) was added in each well and incubated for 2 hours at $37^{\circ} \mathrm{C}$. After removing the receptor solution from wells, ghrelin conjugated with biotin $(750 \mathrm{ng} / \mathrm{mL})$ and mimetics (different concentrations) were incubated for 2 hours at $37^{\circ} \mathrm{C}$. The plate was washed with wash buffer 3 times.

\section{Detection step}


A conjugate of streptavidin - horseradish peroxidase was used to capture the biotinylated ghrelin on the receptor. $100 \mu \mathrm{L}$ of $0.1 \mu \mathrm{g} / \mathrm{mL}$ conjugate in conjugate buffer was added to each well and incubated at $37^{\circ} \mathrm{C}$ for 1 hour. The plate was washed extensively with wash buffer 5 times and $100 \mu \mathrm{L}$ of TMB substrate was added to each well and incubated at $37^{\circ} \mathrm{C}$ for $\sim 20 \mathrm{~min}$ after which stop solution $(0.18 \mathrm{M} \mathrm{H} 2 \mathrm{SO} 4)$ was added and the absorbance was measured at 450 nm using Thermo Multiskan plate reader.

\section{Optimization of coating process}

The 96-wells microplate was coated with streptavidin at several concentrations and in different buffer solutions in order to establish the optimized conditions for the coating process. Taking into consideration that the tetrameric form of streptavidin has an isoelectric point around 5.0 and the maximum concentration of protein that adsorbs on one well is approximately 100 $\mathrm{ng} / \mathrm{cm}^{2}$, we tested the following experimental conditions (Table S1):

Table S1 Optimization of streptavidin concentration and $\mathrm{pH}$ buffer in the coating process of the microplate

\begin{tabular}{ll}
\hline Buffer solution & $\begin{array}{l}\text { Streptavidin } \\
(\mu \mathrm{g} / \mathrm{mL})\end{array}$ \\
\hline 0.1M Acetic Acid / Sodium Acetate $\mathrm{pH} 3.7$ & 0.156 \\
0.05M Citric Acid / Sodium Acetate $\mathrm{pH} 5.0$ & 0.313 \\
0.05M Citric Acid / Sodium Acetate $\mathrm{pH} 6.0$ & 0.625 \\
10mM PBS pH 7.4 & 1.25 \\
0.05M Sodium Hydrogen Carbonate / Sodium & 2.5 \\
Carbonate pH 9.6 & 5.0 \\
\hline
\end{tabular}

Each buffer solution was tested with all streptavidin concentrations. Incubation of streptavidin in buffer solutions was done at $4^{\circ} \mathrm{C}$ for at least 18 hours (over-night). Unbound streptavidin was removed in a washing step (3 times x 5 minutes) incubation at room temperature with PBS + $0.05 \%$ Tween 20. After this step, the microplate was incubated with $0.5 \mu \mathrm{g} / \mathrm{mL}$ biotinylated antibody anti-GHSR1a for 2 hours at $37^{\circ} \mathrm{C}$. The bio-conjugate STR-HRP $0.1 \mu \mathrm{g} / \mathrm{mL}$ prepared in PBS $+0.05 \%$ Tween $20+1 \%$ BSA was added in each well and incubated for 1 hour at $37^{\circ} \mathrm{C}$. The product of the enzymatic reaction of HRP in the presence of TMB as substrate was used to quantify the amount of streptavidin coated in each experiment. All the measurements were done at $450 \mathrm{~nm}$. 


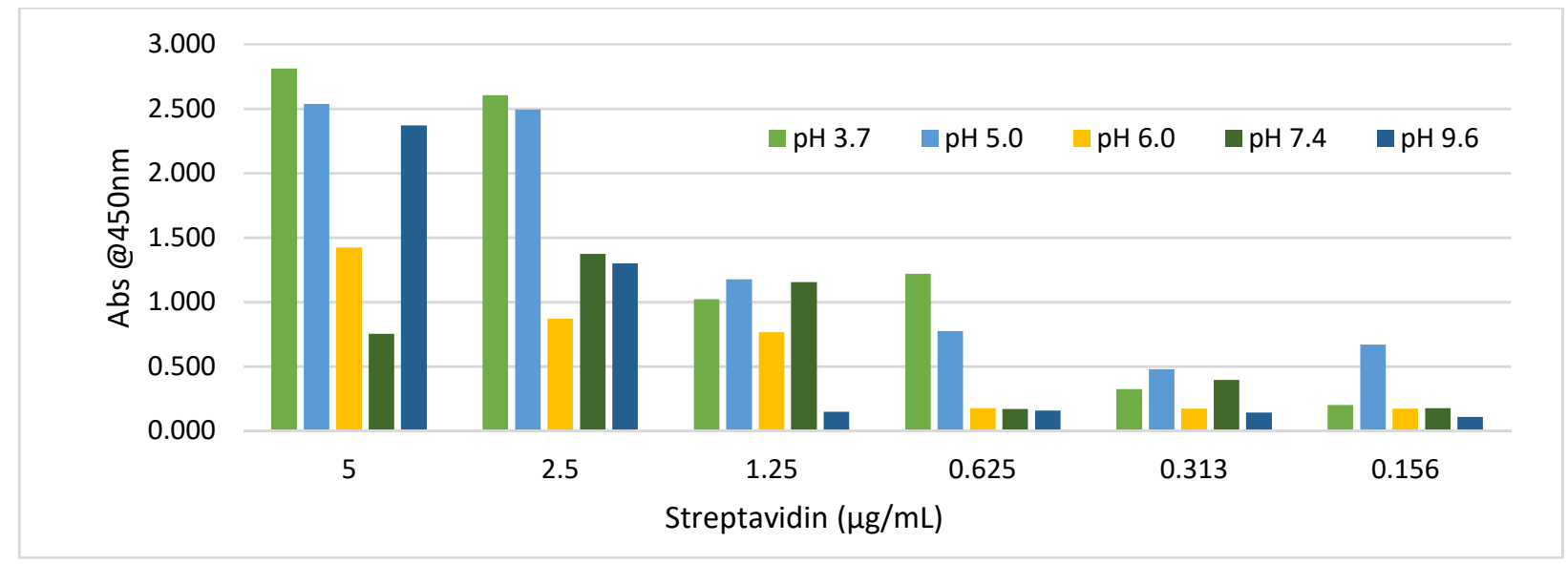

Figure S2 Influence of $\mathrm{pH}$ and streptavidin concentration in the coating process of the microplate. The absorbance is directly proportional to amount of biotinylated anti-GHS-R1a bound to the surface and consequently to the adsorbed streptavidin. Acidic pHs provided the highest load of streptavidin.

\section{Optimization of blocking step}

To minimize the influence of the non-specific binding sources (free binding sites of coated streptavidin, free biotin sites from anti-ghrelin receptor antibody), we tested several classical blocking buffers (BSA, dry milk, etc.), but the optimal results were achieved when using the strong interaction between streptavidin and biotin, in order to block all the free binding sites on the tetrameric form of streptavidin. Blocking in a 3-step incubation (10 minutes each step) with $2.5 \mu \mathrm{g} / \mathrm{mL}$ of biotin, then $2.5 \mu \mathrm{g} / \mathrm{mL}$ of streptavidin and in the final step, again $2.5 \mu \mathrm{g} / \mathrm{mL}$ of free biotin.

Optimization of the concentration of streptavidin and biotin used in blocking step was done in 2 similar experiments:

a) for optimization of streptavidin concentration:

- $\quad 1 \mu \mathrm{g} / \mathrm{mL}$ of anti-ghrelin antibody was incubated for 18 hours (over-night) at $4^{\circ} \mathrm{C}$ in a microplate;

- the plate was washed with wash buffer 3 times;

- several concentrations $(0,1.5,2,3,4$ and $5 \mu \mathrm{g} / \mathrm{mL})$ of streptavidin were incubated for 1 hour at $37^{\circ} \mathrm{C}$;

- $100 \mu \mathrm{L}$ of $0.1 \mu \mathrm{g} / \mathrm{mL}$ conjugate in conjugate buffer was added to each well and incubated at $37^{\circ} \mathrm{C}$ for 1 hour;

- the plate was washed extensively with wash buffer 5 times; 
- $\quad 100 \mu \mathrm{L}$ of TMB substrate was added to each well and incubated at $37^{\circ} \mathrm{C}$ for $\sim 20 \mathrm{~min}$ after which stop solution $\left(0.18 \mathrm{M} \mathrm{H}_{2} \mathrm{SO}_{4}\right)$ was added and the absorbance was measured at $450 \mathrm{~nm}$ using Thermo Multiskan plate reader.

b) for optimization of free biotin concentration:

- $\quad 1 \mu \mathrm{g} / \mathrm{mL}$ of anti-ghrelin antibody was incubated for 18 hours (over-night) at $4^{\circ} \mathrm{C}$ in a microplate;

- the plate was washed with wash buffer 3 times;

- $\quad 2.5 \mu \mathrm{g} / \mathrm{mL}$ of streptavidin was incubated for 1 hour at $37^{\circ} \mathrm{C}$;

- several biotin concentrations $(0,0.625,1.25,2.5$ and $5 \mu \mathrm{g} / \mathrm{mL})$ were incubated for 1 hour at $37^{\circ} \mathrm{C}$;

- $100 \mu \mathrm{L}$ of $0.1 \mu \mathrm{g} / \mathrm{mL}$ conjugate in conjugate buffer was added to each well and incubated at $37^{\circ} \mathrm{C}$ for 1 hour;

- the plate was washed extensively with wash buffer 5 times;

- $\quad 100 \mu \mathrm{L}$ of TMB substrate was added to each well and incubated at $37^{\circ} \mathrm{C}$ for $\sim 20 \mathrm{~min}$ after which stop solution $\left(0.18 \mathrm{M} \mathrm{H}_{2} \mathrm{SO}_{4}\right)$ was added and the absorbance was measured at $450 \mathrm{~nm}$ using Thermo Multiskan plate reader.

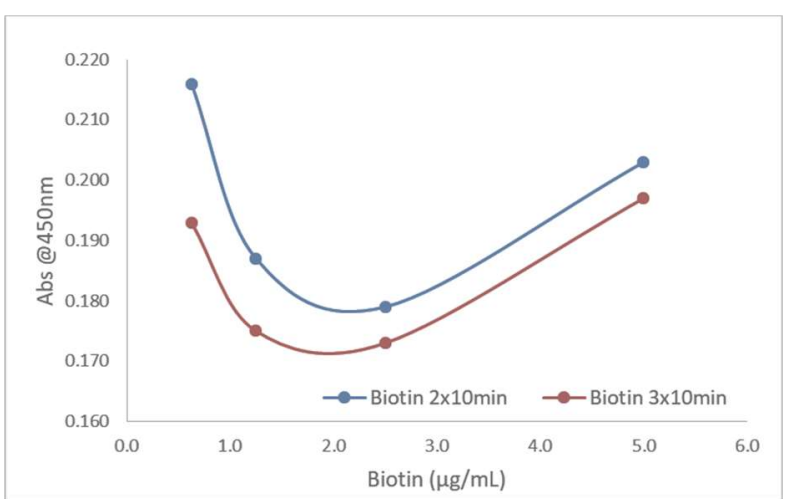

Figure S3A Blocking of free binding sites of streptavidin after immobilization of antibody. Two protocols were tested: blocking with biotin with different concentrations for a) 2 times for 10 minutes and b) 3 times for 10 minutes at room temperature. In the subsequent experiments, the blocking process was performed 3 times for 10 minutes at room temperature with $2.5 \mu \mathrm{g} / \mathrm{mL}$ biotin.

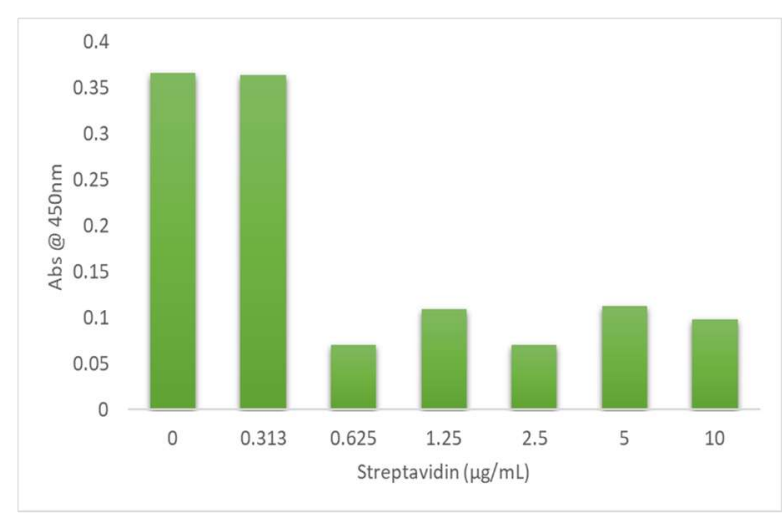

Figure S3B Blocking of biotinylated antibody anti-GHSR1a $(0.5 \mu \mathrm{g} / \mathrm{mL})$ after binding on coated streptavidin with different concentrations of free streptavidin. Blocking process was carried out in 2 steps: 10 minutes at room temperature. Optimized concentration of streptavidin is $2.5 \mu \mathrm{g} / \mathrm{mL}$. 
Supporting Information

\section{Optimization of bio-conjugate concentration}

A bio-conjugate streptavidin - horseradish peroxidase (STR-HRP) was used for the detection of biotinylated ghrelin. To obtain a stable and reproducible signal in the detection step, we tested several concentrations of bio-conjugate, from 0 to $100 \mathrm{ng} / \mathrm{mL}$. $100 \mu \mathrm{L}$ of each concentration of bio-conjugate was added in the wells and $100 \mu \mathrm{L}$ of TMB solution. $\sim 20$ min after which stop solution $\left(0.18 \mathrm{M} \mathrm{H}_{2} \mathrm{SO}_{4}\right)$ was added and the absorbance was measured at 450 nm using Thermo Multiskan plate reader.

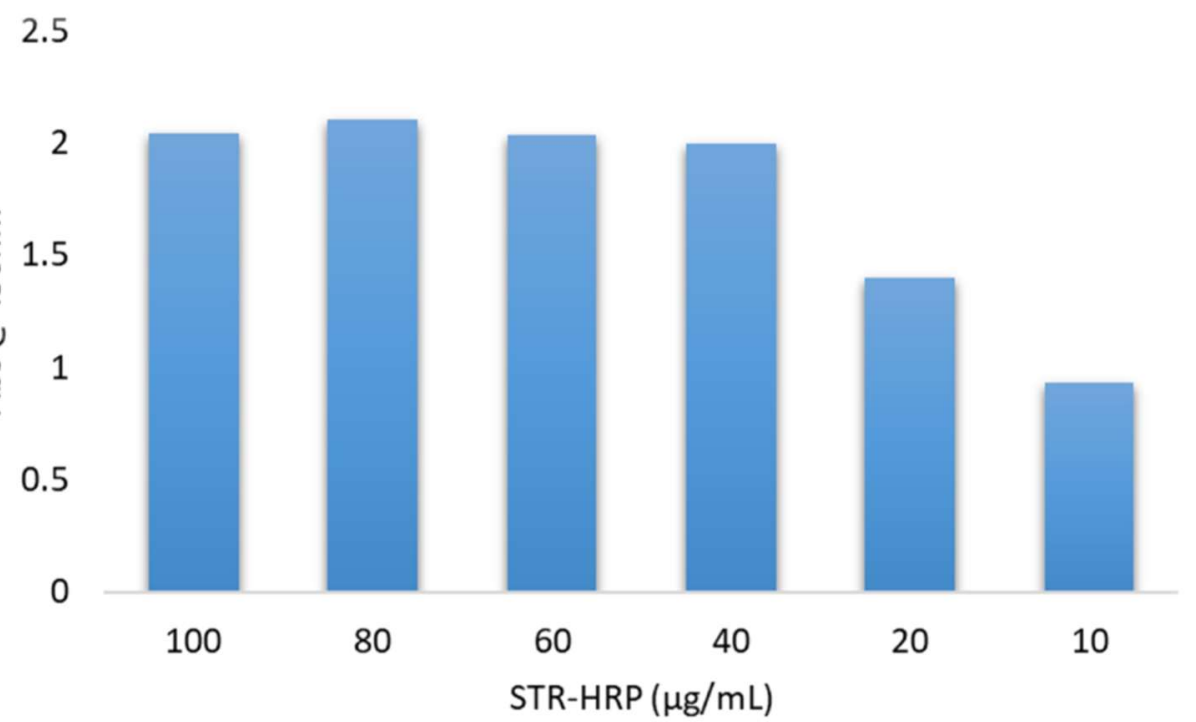

Figure S4 A bio-conjugate streptavidin-horseradish peroxidase (STR-HRP) was used for the detection of biotinylated ghrelin. The optimized concentration of bio-conjugate was $100 \mathrm{ng} / \mathrm{mL}$ prepared in $10 \mathrm{mM}$ PBS buffer containing 1\% BSA and $0.05 \%$ Tween 20 . 
Supporting Information

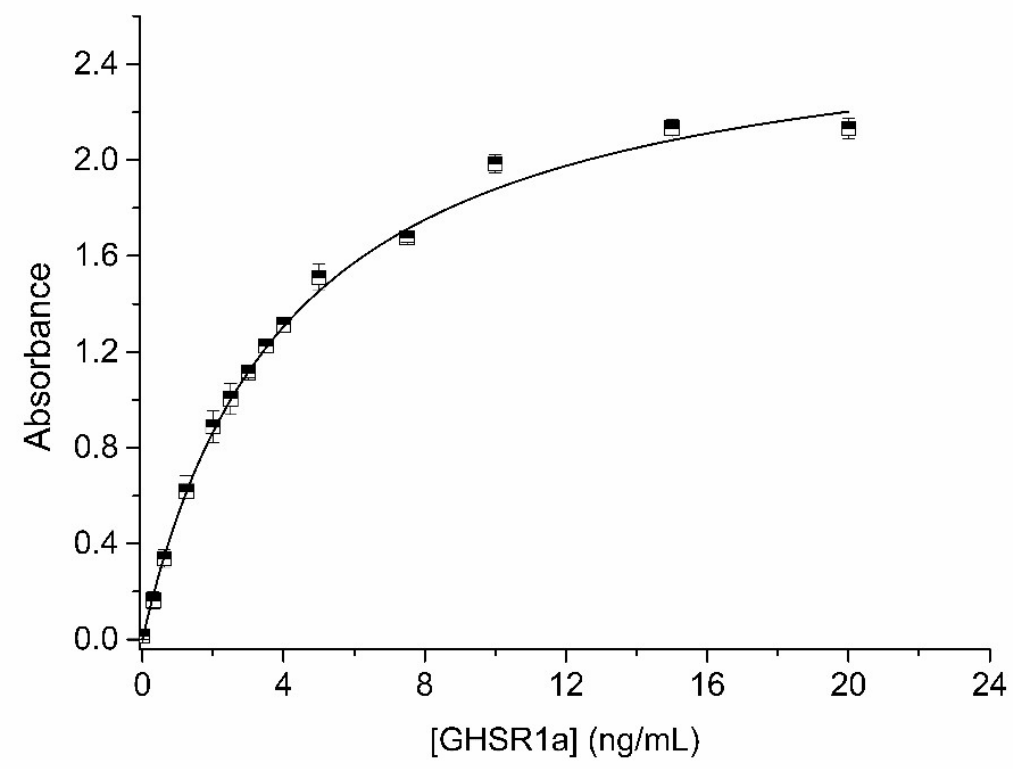

Figure S5 Calibration curve for the detection of active GHS-R1a receptor in an ELISA sandwich assay. All binding experiments were performed in $10 \mathrm{mM}$ PBS buffer, $\mathrm{pH} 7.4$ and $37^{\circ} \mathrm{C}$. 
Table S2 Affinity/dissociation constants estimated through non-linear regression analysis using the "two-binding site" model for competitive binding assays with bio-GHR and antagonists (10 $\mathrm{mM}$ PBS buffer, $\mathrm{pH} 7.4$ at $\left.37^{\circ} \mathrm{C}\right)$

\section{$\begin{array}{llll}\text { Dissociation constant } & \text { DLS } & \text { YIL-781 } & \text { L-692.585 }\end{array}$}

$(\mathrm{nM})$

$\begin{array}{llll}\mathrm{K}_{1}{ }^{-1} \text { (determined in direct } & 89.0 \pm 6.8 & 89.0 \pm 6.8 & 89.0 \pm 6.8\end{array}$

binding experiments with GHR)

$\begin{array}{llll}\mathrm{K}_{2}{ }^{-1} \text { determined in competitive } & 1509 \pm 103 & 2164 \pm 112 & 0.634 \pm 0.059\end{array}$

binding experiments with

GHR/antagonist

$\mathrm{K}_{3}{ }^{-1}$ determined in competitive $\quad 171.4 \pm 1.6 \quad 189 \pm 16 \quad 31.7 \pm 1.4$

binding experiments with

GHR/antagonist

$\mathrm{K}_{4}{ }^{-1}$ determined in competitive $\quad 82.95 \pm 7.22 \quad 72.6 \pm 6.7 \quad 1.15 \pm 0.11$

binding experiments with

GHR/antagonist

$\mathrm{K}_{5}{ }^{-1}$ determined in competitive $\quad(1.05 \pm 0.13) \times 10^{9} \quad(1.16 \pm 0.18) \times 10^{9} \quad(1.22 \pm 0.13) \times 10^{9}$ binding experiments with

GHR/antagonist

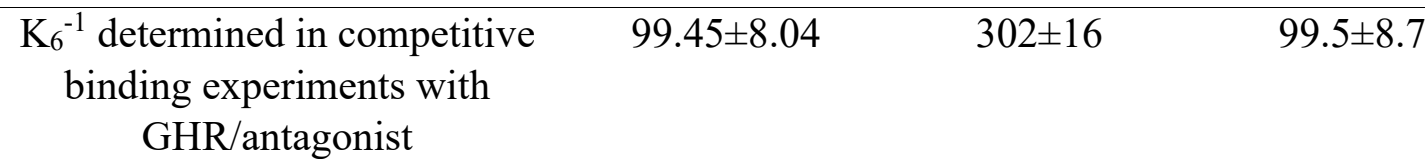



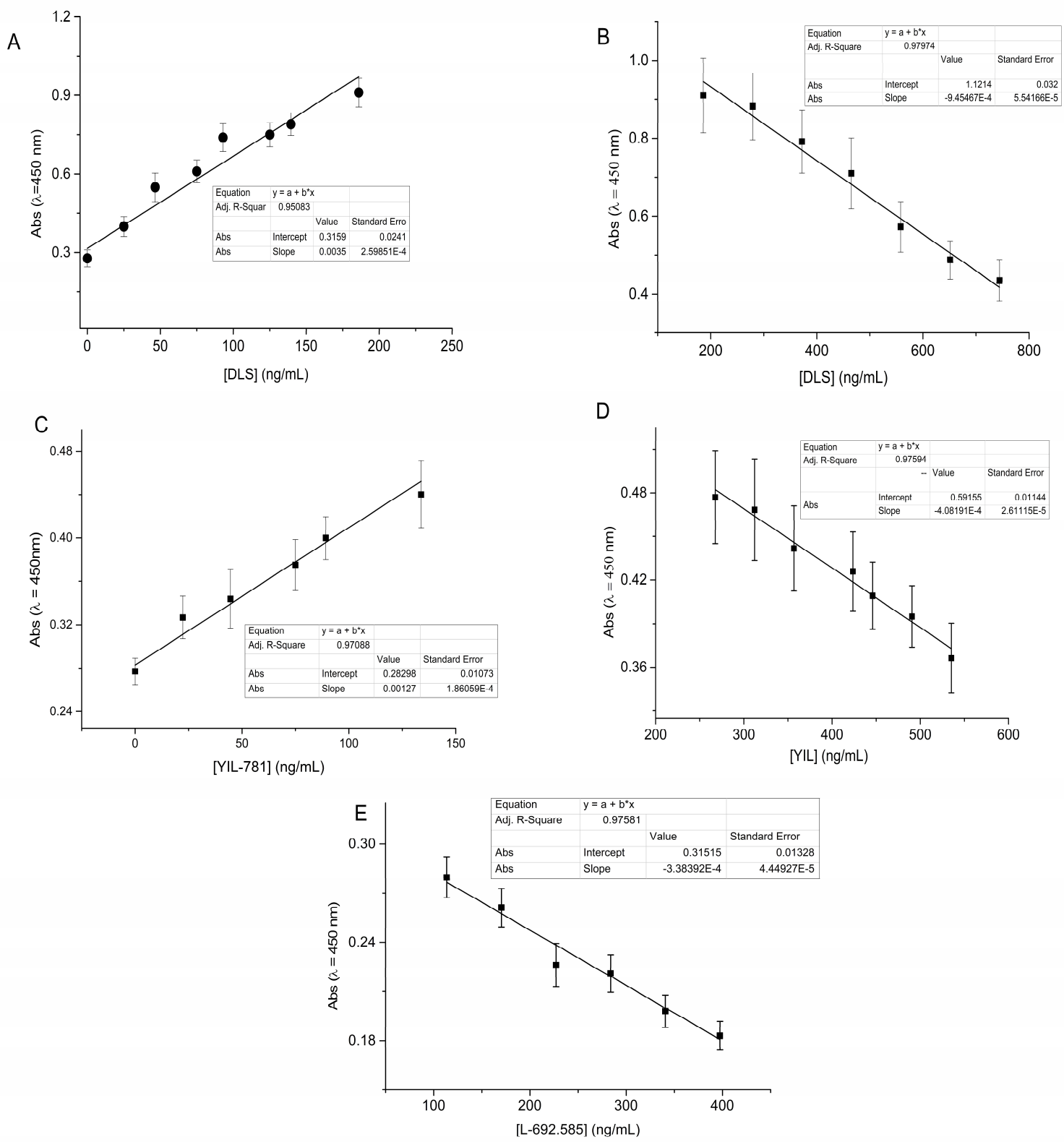

Figure S6 Calibration plots exploiting the linear parts of the binding curves in competitive assays with bio-GHR and antagonists. DLS exhibit a linear range with positive slope within 10-200 ng/mL (A) and a linear range with a negative slope within 200-750 ng/mL (B). A similar behaviour was displayed by YIL-781 within 25-150 ng/mL (C) and 250-550 ng/mL (D). L-692,585 can be detected using only the linear range with the negative slope $(100-400$ $\mathrm{ng} / \mathrm{mL})(\mathrm{E})$. 

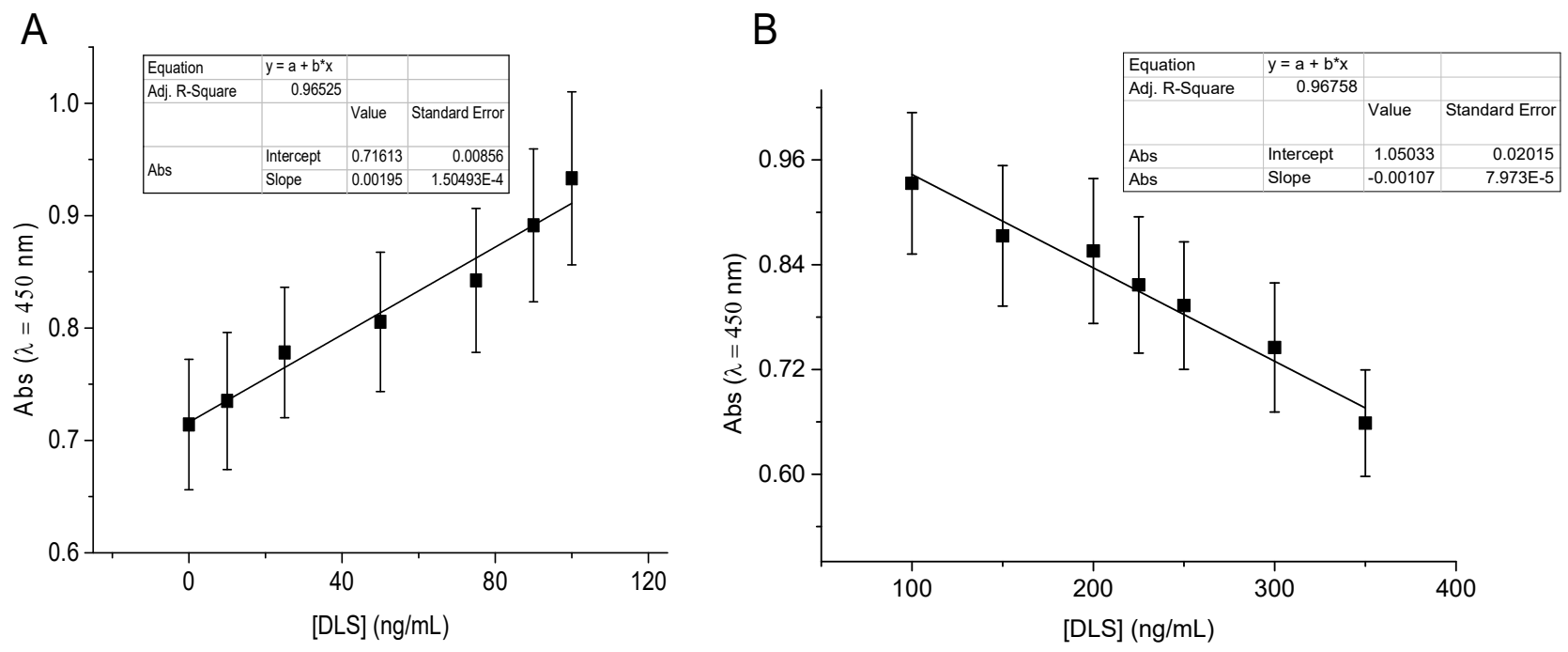

Figure S7 Calibration plots for DLS detection in diluted urine samples with PBS (1:4 $\mathrm{v} / \mathrm{v}$ ). Of note, the matrix influences the sensitivity of the two domains quite differently, as the positive slope decreases (A) and the negative slope increases (B). All experiments were performed at $37^{\circ} \mathrm{C}$. 